\title{
Curriculum for early education in Romania - critical analysis
}

Adela-Simina Câmpan \& Mușata Bocoṣ 


\title{
Curriculum for early education in Romania - critical analysis
}

\author{
Adela-Simina Câmpan ${ }^{\text {a*}}$, Mușata Bocoș ${ }^{\mathrm{b}}$ \\ ${ }^{a}$ Doctoral School "Educational, Reflection, Development", Babeș-Bolyai University, 7 Sindicatelor Street, Cluj-Napoca, 400029, Romania \\ ${ }^{b}$ Faculty of Psychology and Educational Sciences, Babeș-Bolyai University, 7 Sindicatelor Street, Cluj-Napoca, 400029, Romania
}

*Corresponding author: adela.campan@yahoo.com

Abstract

Keywords:

curriculum; early education; outdoor education
The curriculum for early education represents the foundation for the activities performed in nurseries and kindergartens in Romania. This document systematically addresses the field of early education, including both preschool and antepreschool education. The goals of early education are aimed at the five areas of child development, encouraging the overall development of the child and taking into account the child's future competences. The game remains the fundamental activity of ante-preschoolers and pre-schoolers. Thus, the importance of free play is highlighted. The Curriculum for early education comprises the first mentions regarding outdoor activities. Although the concept of outdoor education is not defined, explained or exemplified, it is desirable that children face different climatic conditions and that they play diverse outdoor games.
Zusammenfasung

Schlüsselworte:

Lehrplan;

Früherziehung;

Outdoor-Bildung
Der Lehrplan für die Früherziehung ist die Grundlage für die Tätigkeit von Kinderkrippen und Kindergärten in Rumänien. Dieses Dokument befasst sich systematisch mit der frühkindlichen Erziehung, die sowohl die vorschulische als auch die kleinkinderliche Bildung einschließt. Die Ziele der frühkindlichen Erziehung konzentrieren sich auf die fünf Bereiche der kindlichen Entwicklung, fördern die Gesamtentwicklung des Kindes und berücksichtigen seine zukünftigen Kompetenzen. Das Spiel bleibt die Grundaktivität der Kleinkinder und Vorschulkinder, wobei die Bedeutung des freien Spiels hervorgehoben wird. Mit der Genehmigung des Curriculums für die frühkindliche Erziehung erscheinen die ersten Erwähnungen über Outdoor-Aktivitäten. Obwohl das Konzept der Outdoor-Bildung nicht definiert, erklärt oder veranschaulicht wird, ist es empfehlenswert, Kinder den klimatischen Bedingungen auszusetzen und Outdoor-Spiele zu spielen.

\section{Introduction}

The curriculum for early education (of children from birth to 6 years old) is the official document that underlies all the activity carried out in the preschool and antepreschool education units in Romania starting with the 2019-2020 school year. If the previous curriculum referred only to preschool (Curriculum pentru învăţământul preşcolar (3-6/7 ani), 2008), this new curriculum also includes the period previous to kindergarten, i.e. the nursery. One of the arguments underlying this document is precisely the need to treat early education as a system that includes both nursery and kindergarten education.

According to the Curriculum for early education, the aims mentioned in the document The fundamental benchmarks in early learning and development (Repere fundamentale în invățarea și dezvoltarea timpurie a copilului de la naștere la 7 ani - RFIDT) (Ionescu, Anghelescu \& Boca, 2010) are the foundation of this curriculum. Both the curriculum and the RFIDT support the holistic development of the child, encouraging the development in all five areas of development:

- physical development, health and personal hygiene;

- socio-emotional development;

- cognitive development and knowledge of the world;

- development of language, communication and the premises of reading and writing;

- skills and attitudes in learning.

\section{Outdoor education versus Curriculum for early education}

The curriculum for early education is developed from the perspective of an activating, interactive and integrated pedagogy, centered on the child, offering a document focused on personalized educational approaches and on acquiring behaviors that would underpin the development of later skills, in accordance with the overall development of the preschooler. 
In contrast to the Curriculum for preschool education (Curriculum pentru învăţământul preşcolar (3-6/7 ani), 2008), in the Curriculum for early education (Curriculum pentru Educaţia Timpurie, 2019) the concept of "outdoor activity" is mentioned, emphasizing the idea of changing the location of activities. The two mentions are listed in the Methodology of applying the Education Plan for early education, point 13: "For the games and activities chosen in other spaces than the usual space of the group (outdoor), special attention will be paid both to the organization and arrangement of the playground, as well as the safety offered to the children the respective space and the existing facilities. Also, depending on the space chosen for conducting outdoor activities, which may be outside the institution (park, grass, forest, meadow, farm, grandparents' house, etc.), due consideration will be given to the suitability of the game and the exploration to the conditions offered by it." (Curriculum pentru Educaţia Timpurie, 2019, p. 10). We find that, although no details are made regarding the definition of this concept, it is emphasized the importance of the proper arrangement of the outdoor space in order to ensure the safety of the children and to adapt the activities to the existing conditions.

In addition to the aforementioned specifications, the idea of the outdoors is mentioned. Thus, in the presentation of the Methodology for applying the Education Plan for early education, point 6, outdoor activities are highlighted as a thematic activity specific to preschool education: "The thematic activities - AT (preschool level) are: [...] and Outdoor activities (tools of achievement: walks, sand games, games and sports competitions, use of age-appropriate play equipment)" (Curriculum pentru Educaţia Timpurie, 2019, p. 9).

Point 25 in the Methodology for applying the Education Plan for early education highlights the possibility of carrying out the activity or the sequence of movement in the form of an outdoor walk, as well as the obligation of daily exposure of children to the natural environment, regardless of climate change: "In the daily program it is obligatory to have at least one activity or moment/ sequence of movement (movement game with text and song, physical education activity, refreshment time, sports competitions or routes, outdoor walks, etc.). At the same time, the teacher will consider exposing children to environmental factors, as a condition for maintaining the health and conditioning of the body and will take out children at least once a day, regardless of the season (clear and explicit mentions related to this aspect will be included in the Educational Contracts made with the parents)" (Curriculum pentru Educaţia Timpurie, 2019, p. 12).

We find the idea of outdoor activity when exemplifying behaviors in relation to the dimensions and areas of development. Thus, at the ante-preschool level, within the Physical development, personal health and hygiene field, at the dimension of development Coarse motility and fine motor skills in family life contexts, the behavior "1.2. Participate actively in games, dances, outdoor games, etc." (Curriculum pentru Educaţia Timpurie, 2019, p. 18) emphasizes the involvement of the ante-preschooler in the recreational activities in the open air. We find that active participation in outdoor activities of children is encouraged from the time of the nursery.

Also, in the presentation of the daily program of children in kindergartens (groups with normal, extended and weekly program) we find the idea of children participating in outdoor activities both in the stage of games and activities freely chosen, as well as during the phase of personal development activities (ADP), for the interval 11.30-12.30 - in the groups with normal program and 11.00-13.00 - in the groups with extended / weekly program: "Freely chosen games and activities (movement games, fun games, contests, theater shows, literary / musical auditions, outdoor activities, visits, etc.)", "Routines and transitions aimed at preparing children for freely chosen activities and, implicitly, playing games and recreational activities, outdoors individual and collective hygiene skills, order and discipline skills, self-service skills, motor skills, communication and cooperation skills, etc.)" (Curriculum pentru Educaţia Timpurie, 2019, pp. 30-31). For the extended/ weekly program, the time interval $16.00-17.30$ is dedicated to the freely chosen games and activities, implicitly the outdoor activities.

We find that the references to the term "outdoor activity", although they exist, are few in number. We mention that a mere exposure of children in the kindergarten yard, for example, is not an outdoor activity. The meaning of this concept is much deeper, and planning, organizing and carrying out such an activity requires careful preparation, with precise goals. Unlike the previous curriculum (Curriculum pentru învăţământul preşcolar (3-6/7 ani), 2008), the new curriculum mentions the concept of "outdoor activity", but does not provide other details. 
The natural environment is an inexhaustible source of training experiences. Although the curriculum provides for the exposure of children in the open air, the practice and experience of the chair purport the opposite, the children being in the yard during sunny and pleasant periods of time. Moreover, the stipulations of the curriculum make further references to the outdoor activities within the games and the freely chosen activities, the moments of movement, the routines or transitions, their integration in the activities on experiential domains or their focus on the experiential domains being absent.

\section{Outdoor education and the Fundamental benchmarks regarding the early learning and development of the child between birth and 7 years (RFIDT)}

Taking into account the fact that the design of this document took into account the Fundamental benchmarks regarding the early learning and development of the child between birth and 7 years (RFIDT), in the following, we will analyze how outdoor education is viewed in this last document. RFIDT operates with the same areas of development with which the Curriculum for early education operates, encouraging the overall development of the child from birth to 7 years of age. Each of these areas was detailed in the sub-domains of development; the latter have been materialized in a number of specific aspects, and from these the benchmarks have been extracted. We specify that the analysis will be performed only for the age range 3-7 years, a period that overlaps with the preschool education.

In the presentation of the Physical development, health and personal hygiene field is described the importance of outdoor movement as a basic element for personal health and hygiene: "Personal health and hygiene include body hygiene (bathing, dental hygiene, clothing), sleep, nutrition, outdoor movement." (The fundamental benchmarks regarding the early learning and development of the child between birth and 7 years, p. 19).

Within this area, in the sub-domain Physical development, the specific aspect of Coarse motility, for benchmark no. 1: "The child should be able to coordinate the large muscles of the body with a purpose of movement.", age level 61-84 months (5-7 years) it is specified, among others, the following supportive practice: "Give children permanently the opportunity to move outdoors."
For the same domain, sub-domain and specific aspect, in reference 2: "The child should be able to participate in various physical activities." The following support practices are mentioned: for 37-60 months (3-5 years) "Offer to children at least 60 minutes of physical activity daily, indoors or outdoors."; for 61-84 months (5-7 years) - "Provide children with plenty of time every day for outdoor activities and movement and teach them new movements, submit them to new challenges. Exercise their speed, strength, precision."

Within the same domain and subdomain, the specific aspect Sensory-motor development, for benchmark no. 4: "The child should be able to demonstrate the use of the senses (sight, hearing, tactile sense, smell, etc.) in interacting with the environment to guide their movements.", age level 37-60 months (3-5 years), is noted as a supporting practice: "Provide the opportunity to use the play equipment in the outdoor play area".

Specifications of this kind are also found in the field of Skills and attitudes in learning, the subdomain Curiosity and interest, age level 37-60 months (3-5 years); for benchmark 1: "The child should be able to show curiosity and interest in experimenting and learning new things.": "He shows enthusiasm for travelling outdoors and in new places.", "Organize excursions into the neighbourhood or in the community, trips, visits to the zoo, botanical garden, museums, etc.".

Note that the concepts of "outdoor education" or "outdoor activity" do not appear in this document. We note that most mentions are found in the field of Physical development, health and personal hygiene, with the importance of outdoor movement/ activities being highlighted. The field Capacities and attitudes in learning emphasizes the idea of moving towards the natural environment, of giving preschoolers multiple opportunities to explore new outdoor spaces, but which does not refer to the activity of outdoor movement/ play, but to the research of locations that correspond to their knowledge needs.

We also find that in this document there are not too many details regarding outdoor activities, the existing ones focusing on physical activities or environmental knowledge. 


\section{Conclusions}

It is necessary to clearly define the key concepts conveyed and to make official regulations that grant the appropriate status to outdoor education. Although according to its specificity, outdoor education focuses more on the Science and Psychomotor fields, we recommend that the proposal is sustained and that some outdoor activities that are carried out will be based on the other experiential areas too.

In the following, we present a SWOT analysis of the Curriculum for early education:

Table no. 1. SWOT analysis of the Curriculum for early education

\section{Strengths}

- The curriculum for early education was built in accordance with the Romanian educational ideal, respecting the individual and age particularities of ante-preschoolers and preschoolers;

- The curriculum for early education is focused on areas of development, supporting the overall development of the child;

- The curriculum for early education is based on the principle of child-centered education;

- The curriculum for early education operates with the concept of "outdoor activity";

- The curriculum for early education encourages the achievement of freely chosen games and activities, as well as outdoor personal development activities;

- The curriculum for early education encourages partnership with family and community.

\section{Opportunities}

- the possibility of customizing the instructional-educational process, respecting the particularities of the preschoolers and valorizing their potential;

- flexibility in choosing and approaching the contents specific to the experiential fields, as well as in their integration;

- the opportunity to capitalize on the contents specific to all the experimental fields in the outdoor activities;

- the possibility of carrying out outdoor activities in all categories of activities;

- capitalizing on the creative potential of teachers.

\section{Weaknesses}

- The curriculum for early education does not explain the concepts "outdoor education", "outdoor activity";

- The outdoor activities proposed by the curriculum focus mainly on the freely chosen games and activities, the moments of movement or the elements of routine and transition, the outdoor activities within the activities on experiential domains being absent;

- The curriculum for early education makes use to a very small extent of the resources of the environment, which could facilitate the instructional-educational process.
In our opinion, outdoor education has seen a slight growth when the new curriculum became operative. Although there are only a few references to the concept of "outdoor activity", it is encouraging that it exists. We believe that the existence of a support curriculum that would explain, detail and exemplify the content and specificity of outdoor education would be of real benefit to teachers.

Considering the flexibility given to the teacher both from the point of view of the contents, as well as the modalities of carrying out the activities, we consider that the natural environment can be considered as an optimal framework for the instructive-educational process. First of all, certain content is more suitable for being taught and learned outdoors. Secondly, the proposed learning tasks can be much more diversified, generating positive, varied and desirable learning experiences. Last but not least, the possibility to carry out activities outside the four walls of the classroom provides an opportunity for joy, increasing the degree of motivation and offering the opportunity for free manifestation of the child.

In conclusion, we consider that outdoor education should be given the appropriate status within the curriculum (not only in the case of the one for early education), being encouraged to carry it out within each category of learning: freely chosen activities, activities on experiential fields and personal development activities. In this way, we will achieve positive results at the level of preschoolers both in the short term (knowledge) and in the long term (skills, attitudes, behaviors, etc.).

\section{Authors note:}

The authors have equal contributions to this article.

Adela-Simina Câmpan is a preschool teacher at "Linden perfume" Kindergarten, with extended program, in Cluj- 
Napoca and PhD Student at the Faculty of Psychology and Sciences of Education (Babeș-Bolyai University, ClujNapoca, Romania). Her research areas are oriented towards investigating the formative and informative valences of the outdoor type experiential activities in preschool education.

Mușata Bocoș is a University Professor and Ph.D. Coordinator at the Faculty of Psychology and Sciences of Education (Babeș-Bolyai University, Cluj-Napoca, Romania). In 1997, she obtained a Ph.D. in Educational Sciences, at the Babeș-Bolyai University. Her research interests are reflected in a series of studies and articles published in important national and international journals. Her teaching activity covers several areas, such as the curriculum theory and methodology, general didactics, and educational research.

\section{References}

Ionescu, M. (coord.), Anghelescu, C. \& Boca, C. (2010). Repere fundamentale în învățarea și dezvoltarea timpurie a copilului de la naștere la 7 ani. București: Editura Vanemonde.

*** Ministerul Educației Naţionale. (2019). Curriculum pentru educația timpurie. Available at: https://www.edu.ro/sites/default/files/Curriculum\%20ET_20 19_aug.pdf (accessed at 17.09.2019).

*** Curriculum pentru învăţământul preşcolar (3-6/7 ani). (2008). Available at: http://www.isj.albanet.ro/_documente/078_curriculum_presc olar_2008.pdf (accessed at 10.02.2019). 